\title{
Testing Methods Affecting the Antagonistic Ability of Pseudomonas Biocontrol Strains
}

\author{
${ }^{1}$ I. JEVCSÁK, ${ }^{2}$ B. OLDAL, ${ }^{1}$ L. KÖDÖBÖCZ and ${ }^{1}$ M. KECSKÉS \\ ${ }^{1}$ Szent István University, Agricultural, Environmental Microbiology and Soil Bio- \\ technology PhD Programme, Budapest and ${ }^{2}$ Research Institute for Soil Science and \\ Agricultural Chemistry (RISSAC) of the Hungarian Academy of Sciences, Budapest
}

\section{Introduction}

As fungicides may have disadvantageous effects on human health and the environment, alternative control procedures - biological control - are currently being developed. In the last decades therefore several micro-organisms have been tested to determine their abilities to suppress the soil-borne phytopathogens. Physical and chemical characteristics of the rhizosphere environment are determined by the interaction of soils, plants, and organisms associated with the root, including bacteria, fungi, protozoa, and nematodes (ELLIOT et al., 1984; YANG \& CROWLEY, 2000). Root exudates provide micro-organisms with the necessary nutrients, rhizobacteria on the other hand can improve the crop yields (FEDI et al., 1997; BUYSENS et al., 1999). Some rhizobacteria, which are commonly called plant growth promoting rhizobacteria (PGPR), can protect the roots against pathogenic micro-organisms (KLOEPPER \& SCHROT, 1978; LIGON et al., 2000). There are several mechanisms behind this beneficial behaviour, such as siderophore production, fast growing ability or release of some antibiotic compounds. The PGPR effect, therefore is the result of a complex interaction (BIRÓ et al., 1998). Under temperate climatic circumstances pseudomonads are common and ubiquitous members of the rhizobacterial microbiota in soils. These beneficial effects develop either in the form of suppression of diseases and deleterious effects caused by the soil-borne pathogens (WELLER, 1988; COOK, 1993) or in the form of better growth and fitness due to the secondary metabolite production. Fluorescent-putida type pseudomonads are the most commonly studied biopesticides (SCHWYN \& NEILANDS, 1987).

Correspondence to: Bálint OLDAL, Research Institute for Soil Science and Agricultural Chemistry (RISSAC) of the Hungarian Academy of Sciences, H-1022 Budapest, Herman Ottó út 15. Hungary. E-mail: oldal@rissac.hu 
The aim of this work was to isolate and select antagonistic microbes (Pseudomonas strains) against the soil-borne pathogens of potato (Solanum tuberosum L.). The long-term crop rotation experiment of Westsik (Nyíregyháza, Hungary), provided unique possibilities for the appropriate strain isolation of the antagonists.

\section{Materials and Methods}

Twenty-six Pseudomonas strains were isolated from potato tubers (Solanum tuberosum L.) from different plots and treatments of the Westsik crop rotation experiment. The plots were treated by 3 types of organic fertilizer (straw, green manure and farmyard manure), enriched with different amounts of inorganic $\mathrm{N}$, $\mathrm{P}$ and $\mathrm{K}$ fertilizers, which resulted in various fertile and natural conditions. Thirteen strains were identified as Pseudomonas aeruginosa by 16S rDNS (RAINEY et al., 1996; SAMBROOK et al., 1989; ALTSCHUL et al., 1997). Identification of the other tested Pseudomonas group is still in progress. Using selective media and some other biochemical tests and genotype analyses (ARDRA), they are preliminary characterized as members of the fluorescens-putida group. Strains involved in this study were previously tested and selected for their siderophore production on CAS agar plates by a modified procedure (SCHWYN $\&$ NEILANDS, 1987). The list and origin of the strains are given in Table 1.

The strains were individually tested for their ability to inhibit the mycelium growth of Rhizoctonia solani (Kühn) DSM No. 843 (Deutsche Sammlung von Mikroorganismen und Zellkulturen, Braunschweig, Germany) = ATCC 13289 (American Type Culture Collection) and Fusarium solani F.00715 (Collection of Agricultural and Industrial Micro-organisms, Szent István University, Buda-

Table 1

Code and origin of the investigated Pseudomonas sp. strains

\begin{tabular}{|l|l|l|l|l|}
\hline \multirow{2}{*}{$\begin{array}{c}\text { Pseudomonas } \\
\text { spp. types }\end{array}$} & I. uncultivated & $\begin{array}{c}\text { IV. straw } \\
(26.1 \mathrm{t} / \mathrm{ha} / 3 \text { years })\end{array}$ & $\begin{array}{c}\text { VIII. green } \\
\text { manure (N.D.) }\end{array}$ & $\begin{array}{c}\text { IX. farmyard } \\
\text { manure } \\
(26.1 \mathrm{t} / \mathrm{ha} / 3 \text { years })\end{array}$ \\
\cline { 2 - 5 } & A10; AX & $\begin{array}{l}\text { A5/2; A35/2; } \\
\text { A20 }\end{array}$ & A6; A9; A34 & $\begin{array}{l}\text { A16; A23/1; } \\
\text { A28a; A30/2; } \\
\text { A36 } 6\end{array}$ \\
\hline $\begin{array}{l}\text { Fluorescens- } \\
\text { putida type } \\
\text { Pseudomonads }\end{array}$ & F1; F2 & F4; F8; F12 & F15; F22; F38 & $\begin{array}{l}\text { F41; F44; F47; } \\
\text { D65; D80 }\end{array}$ \\
\hline
\end{tabular}

*Treatments were enriched with inorganic fertilizers, as follows: $\mathrm{I}=32.5 \mathrm{~kg} / \mathrm{ha} \mathrm{N}, 25 \mathrm{~kg} / \mathrm{ha}$ $\mathrm{P}$ and $20.5 \mathrm{~kg} / \mathrm{ha} \mathrm{K}$; IV $=50 \mathrm{~kg} / \mathrm{ha} \mathrm{N}, 50 \mathrm{~kg} / \mathrm{ha} \mathrm{P}$ and $16.2 \mathrm{~kg} / \mathrm{ha} \mathrm{K} ; \mathrm{VIII}=50 \mathrm{~kg} / \mathrm{ha} \mathrm{P}$ and $16.2 \mathrm{~kg} / \mathrm{ha} \mathrm{K} ; \mathrm{IX}=50 \mathrm{~kg} / \mathrm{ha} \mathrm{N}$. N.D. $=$ not determined 
pest, Hungary). Experiments were set up with malt-yeast extract solid agar medium (yeast extract $3.0 \mathrm{~g}$, malt extract $3.0 \mathrm{~g}$, proteose pepton $5.0 \mathrm{~g}$, glucose $10.0 \mathrm{~g}$, agar $20.0 \mathrm{~g}$, dissolved in 1 litre of distilled water) by two different techniques:

a) Two loopful colonies of a bacterial strain (after a 24-hour incubation) were placed on opposing edges of the $90 \mathrm{~mm}$ Petri dish (spot transfer). One colony of a phytopathogenic fungus on a $5 \mathrm{~mm}$ agar disk was placed in the centre of the plate.

b) The bacterial suspensions were spread on the medium (spread plate). The pathogen on a $5 \mathrm{~mm}$ agar disk was placed in the centre of the plate.

Each combination of pathogens and antagonists was replicated three times and incubated at $26-28{ }^{\circ} \mathrm{C}$. Eight days later, the fungal growth was measured. To estimate the inhibition activity of bacterial strains, the principal inhibition ratio of fungal colonies (PI\%) was established. In case of spot transfer: $\mathrm{PI} \%=$ $(\mathrm{C}-\mathrm{S}) / \mathrm{C} \cdot 100$; where $\mathrm{C}=$ diameter $(\mathrm{mm})$ of the control colony of fungi tested, $\mathrm{S}$ $=$ short diameter $(\mathrm{mm})$ of tested fungal colony developed in an elliptic form. In case of spread plate: $\mathrm{PI} \%=(\mathrm{C}-\mathrm{T}) / \mathrm{C} \cdot 100$; where $\mathrm{T}=$ diameter $(\mathrm{mm})$ of treated colony of the pathogen fungi tested, $\mathrm{C}=$ diameter $(\mathrm{mm})$ of the control colony of pathogenic fungi. Data were subjected to analysis of variance (ANOVA). Means of the antagonistic ability are presented in the tables.

\section{Results}

\section{Sensitivity of pathogens against Pseudomonas strains}

All tested strains showed strong inhibition of the fungus Rhizoctonia solani ATCC 13289 and also of the fungus Fusarium solani F.00715 (Tables 2 and 3). Rhizoctonia, however was found to be more sensitive with both used techniques. The sensitivity range of $R$. solani ranged from 3.5 to $98.6 \mathrm{PI} \%$; in the case of $F$. solani it was between 21.2 and $79.3 \mathrm{PI} \%$. This behaviour, however can hardly be generalized, due to the fact that only one Fusarium and one Rhizoctonia strain was tested. The antagonistic activity of bacterial strains varied greatly with the two different testing methods. The strongest inhibition was recorded with the spread plate technique, where a direct contact could develop between the two microbes.

\section{Antagonistic ability of the Pseudomonas strains}

Pseudomonads were isolated from the various treatments of the Westsik long-term crop rotation experiment. All of them were selected for a positive siderophore production, which is one of the mechanisms involved in the antagonistic ability. Results are shown in Tables 2 and 3. In general, the highest 
Table 2

Antagonistic effect of Pseudomonas sp. strains against Rhizoctonia solani ATCC 13289, in decreasing order (MI\%)

\begin{tabular}{|l|l|l|r|l|r|l|r|}
\hline \multicolumn{3}{|c|}{ Principal inhibition ratio of fungal colonies by Pseudomonas sp. strains } \\
using two different in vitro techniques (PI\%) \\
\hline \multicolumn{3}{|c|}{ Spread plate } & \multicolumn{3}{c|}{ Spot transfer } \\
\hline \multicolumn{2}{|c|}{ P. aeruginosa } & \multicolumn{2}{|c|}{ P. sp. } & \multicolumn{2}{c|}{ P. aeruginosa } & \multicolumn{2}{c|}{ P. sp. } \\
\hline Strain & MI\% & Strain & MI\% & Strain & MI\% & Strain & MI\% \\
\hline A9 & 98.6 & D80 & 98.6 & A10 & 53.8 & F4 & 41.2 \\
A5/2 & 88.1 & F2 & 81.8 & A5/2 & 47.6 & D80 & 21.7 \\
A6 & 86.7 & F8 & 76.2 & A9 & 32.8 & F12 & 16.1 \\
A35/2 & 81.1 & D65 & 46.9 & A35/2 & 32.8 & D65 & 11.9 \\
A28a & 76.9 & F1 & 37.8 & A23/1 & 24.5 & F41 & 10.5 \\
A34 & 76.9 & F15 & 35.7 & A16 & 22.4 & F38 & 9.1 \\
A16 & 76.9 & F44 & 27.3 & AX & 21.7 & F2 & 7.7 \\
A10 & 76.9 & F4 & 25.2 & A28a & 21.0 & F8 & 7.0 \\
A23/1 & 74.8 & F12 & 16.1 & A20 & 16.1 & F1 & 6.3 \\
AX & 70.6 & F41 & 9.8 & A6 & 15.4 & F47 & 5.6 \\
A20 & 70.6 & F38 & 6.3 & A34 & 15.4 & F22 & 5.6 \\
A30/2 & 67.8 & F47 & 5.6 & A30/2 & 11.9 & F15 & 4.2 \\
A36 & 49.6 & F22 & 5.6 & A36 & 3.5 & F44 & 3.5 \\
\hline
\end{tabular}

Table 3

Antagonistic effect of Pseudomonas sp. strains against Fusarium solani F.00715, in decreasing order (MI\%)

\begin{tabular}{|l|l|l|l|l|l|l|l|}
\hline \multicolumn{3}{|c|}{ Principal inhibition ratio of fungal colonies by Pseudomonas sp. strains } \\
using two different in vitro techniques (PI\%) \\
\hline \multicolumn{3}{|c|}{ Spread plate } & \multicolumn{4}{c|}{ Spot transfer } \\
\hline \multicolumn{2}{|c|}{ P. aeruginosa } & \multicolumn{2}{|c|}{ P. sp. } & \multicolumn{2}{c|}{ P. aeruginosa } & \multicolumn{2}{c|}{ P. sp. } \\
\hline Strain & MI\% & Strain & MI\% & Strain & MI\% & Strain & MI\% \\
\hline A9 & 79.3 & F44 & 59.5 & A9 & 53.1 & F12 & 49.5 \\
A5/2 & 56.8 & D80 & 54.1 & A5/2 & 52.7 & F15 & 35.6 \\
A35/2 & 50.9 & F12 & 48.2 & A10 & 52.2 & F4 & 32.0 \\
A10 & 50.9 & F2 & 44.6 & A35/2 & 50.0 & F47 & 28.3 \\
A20 & 41.9 & F38 & 46.0 & A6 & 41.0 & D80 & 27.9 \\
AX & 44.6 & F1 & 40.5 & A20 & 37.8 & F1 & 27.9 \\
A28a & 44.6 & F15 & 40.5 & AX & 36.5 & F44 & 24.3 \\
A6 & 38.7 & F47 & 41.0 & A30/2 & 36.0 & F22 & 23.0 \\
A34 & 39.6 & F4 & 32.4 & A16 & 31.5 & F41 & 22.0 \\
A23/1 & 36.5 & F8 & 32.4 & A34 & 28.4 & F2 & 22.0 \\
A30/2 & 36.5 & F41 & 22.5 & A23/1 & 28.4 & F8 & 21.6 \\
A16 & 39.2 & F22 & 24.3 & A28a & 27.5 & F38 & 21.6 \\
A36 & 26.1 & FD65 & 21.2 & A36 & 27.0 & D65 & 21.2 \\
\hline
\end{tabular}

$P$. sp.: fluorescens-putida type Pseudomonas strains 
value of inhibition was observed in the case of Pseudomonas aeruginosa strains. The other group of fluorescens-putida type pseudomonads, however showed a weaker inhibition activity. Although no such difference is mentioned in literature, results suggest some well distinguishable mechanisms of the antagonistic ability, those are subjects of further studies.

Among the Pseudomonas aeruginosa group, two strains (A9 and A5/2) were the most efficient antagonists. From the other Pseudomonas sp. group, strains D80 and F44 were the best control agents.

Values of significant difference regarding the total average of inhibition levels presented in Tables 2 and 3 are shown in Table 4.

\section{Comparison of in vitro techniques in the antagonistic ability}

All of the tested pseudomonads but few strains significantly inhibited the growth of fungal strains with the two in vitro techniques used. Although the weaker inhibition was observed in the case of spot transfer technique, the strains were still able to inhibit the development of fungal sclerotia during the whole eight-day incubation period.

Table 5, on the other hand, shows the values of significant difference between the two in vitro techniques used for the sensitivity tests. Based on the data obtained, it seems to be clear that there were statistically reliable differences

\section{Table 4}

Significant difference values of simple ANOVA for total mean inhibitory activity of bacterial strains on the tested fungi with two in vitro techniques

\begin{tabular}{|l|c|c|}
\hline \multirow{2}{*}{ In vitro techniques } & \multicolumn{2}{|c|}{ Fungi } \\
\cline { 2 - 3 } & Rh. solani & F. solani \\
\hline Spot transfer & 3.55 & 2.99 \\
Spread plate & 3.34 & 2.11 \\
\hline
\end{tabular}

Table 5

Significant difference values of multiple ANOVA for total mean inhibitory activity of bacterial strains on the fungi tested with two different in vitro techniques

\begin{tabular}{|c|c|c|c|c|}
\hline \multirow{3}{*}{ In vitro techniques } & \multicolumn{4}{|c|}{ Fungi } \\
\hline & \multicolumn{2}{|c|}{ Rhizoctonia solani } & \multicolumn{2}{|c|}{ Fusarium solani } \\
\hline & Mean & SD value & Mean & $\mathrm{SD}$ value \\
\hline Spot transfer & 17.37 & 0.66 & 31.77 & 0.49 \\
\hline Spread plate & 54.39 & & 40.47 & \\
\hline Spot transfer and spread plate & 54.39 & 0.60 & 40.47 & 0.49 \\
\hline
\end{tabular}

SD value: significant difference value 
between the techniques used for inoculation. There is an immanent property of these methods, namely spread plate is significantly more effective (causing larger inhibition zones) than spot transfer. Inhibition is stronger in cases when a direct contact generates between the biocontrol agents and pathogens.

\section{Discussion}

Two different in vitro techniques were used to study the inhibition potential of several beneficial rhizosphere bacteria against two strains of soil-borne plant pathogens. Spread plate technique produced an inhibition ratio of nearly $100 \%$; the spot transfer, however, gave only $50 \%$. This fact confirms the importance of direct contact between the biocontrol agents and target organisms. Either of the reported in vitro techniques can be used to screen the antagonistic behaviour of the strains; indicating a simple pre-selective method for biocontrol bacterial isolates.

The results infer a possible impact of siderophore production in the antagonism too, as all of the investigated bacterial strains were able to produce siderophore-like secondary metabolites, which may cause a nutrient competition effect for the other coexisting micro-organisms (ELLIOT et al., 1984; SCHWYN \& NEILANDS, 1987; COOK, 1993).

The antifungal effects, however presumably depend on several other mechanisms differing from siderophore production; i.e. antibiotic production, growth rate, etc (BIRÓ et al., 1998; BUYSENS et al., 1999). The antagonistic behaviour of a single bacterial strain moreover depends greatly on the pathogens. There are complex interactions among the micro-organisms in the soil-plant system, where the antagonistic abilities are important for the control of soil-borne pathogens.

The antagonism of $P$. aeruginosa strains against phytopathogenic fungi is relatively poorly studied, due to the opportunistic human pathogenic feature of this species. They are however common, ubiquitous components in the soil, having a potential of interacting with the soil microbiota. In the present study, they proved to have significantly higher antagonistic effect against the tested fungi as compared to the other non-pathogen pseudomonads. The members of fluorescens-putida group on the other hand were also reported to be successfully used against soil-borne plant pathogens, such as the apple-replant-disease in pot experiments (WELLER, 1988; BIRÓ et al., 1998).

The use of in vitro selected antagonistic strains which produce the best performance in the real soil-plant systems, is highly encouraged therefore in this study. 


\section{Summary}

The antagonistic effect of thirteen Pseudomonas aeruginosa and thirteen strains of other Pseudomonas species was studied on the soil-borne phytopathogenic Rhizoctonia solani and Fusarium solani fungi.

The inhibition of pathogen colony growth was tested with two different in vitro techniques using the same type of culture media. In case of the spread slant technique the antagonists induced a significantly stronger inhibition on the growth of pathogens than in case of spot transfer. Among the 26 investigated Pseudomonas strains, $P$. aeruginosa strains were generally more effective against the fungal pathogens. Rhizoctonia solani proved to be affected to a greater extent by the bacterial strains studied than the Fusarium solani representative.

The possibility of in vitro strain selection of biocontrol microbes is being further discussed.

Key words: Pseudomonas, Fusarium, Rhizoctonia, biocontrol, in vitro tehniques, comparison

\section{References}

ALTSCHUL, S. F. et al., 1997. Gapped BLAST and PSI-BLAST: a new generation of protein database search programs. Nucleic Acids Res. 25. 3389-3402.

BIRÓ, B. et al., 1993. Effect of fertilizer on spontaneous Rhizobium infection in Hungarian soils. Agrokémia és Talajtan. 42. 207-211.

BIRÓ, B. et al., 1998. Specific replant disease reduced by PGPR rhizobacteria. Acta Hort. 477. 75-81.

BUYSENS, S. et al., 1999. Involvement of pyochelin and pyoverdin in suppression of pythium-induced damping-off of tomato by Pseudomonas aeruginosa 7NSK2. Appl. and Env. Microbiol. 65. (12) 5612-5614.

CoOK, R. J., 1993. Making greater use of introduced microorganisms for biological control of plant pathogens. Annu. Rev. Phytopathol. 31. 53-80.

ElLIOT, L. F. et al., 1984. Bacterial colonization of plant roots. In: Microbial Interactions. (Eds.: TodD, R. L. \& GidDENS, J. E.) 1-16. Soil Sci. Soc. America. Madison, WI.

FEDI, S. et al., 1997. Evidence for signalling between the phytopathogenic fungus Pythium ultimum and Pseudomonas fluorescens F113: P. ultimum represses the expression of genes in $P$. fluorescens F113, resulting in altered ecological fitness. App. Environ. Microbiol. 63. (1) 4261-4266.

KLOEPPER, J. \& SCHROT, M., 1978. Plant growth-promoting rhizobacteria on radishes. Proc. Int. Conf. Plant. Pathog. Bact. 2. 879-882.

LIGON, J. M. et al., 2000. Natural products with antifungal activity from Pseudomonas biocontrol bacteria. Pest Management Sci. 56. 688-695. 
RAINEY, F. A. et al., 1996. The genus Nocardiopsis represents a phylogenetically coherent taxon and distinct actinomycete lineage: proposal of Nocardiopsaceae family. Int. J. Syst. Bacteriol. 46. 1088-1092.

SAMBrooK, J., Fritsch, E. F. \& MANiatis, T., 1989. Molecular Cloning: A Laboratory Manual. $2^{\text {nd }}$ ed. Cold Spring Harbor Laboratory Press. Cold Spring Harbor, N.Y.

SchwYN, B. \& NeILANDS, J. B., 1987. Universal chemical assay for the detection and determination of siderophores. Anal. Biochem. 160. 47-56.

WELLER, D. M., 1988. Biological control of soil-borne pathogens in the rhizosphere with bacteria. Annu. Rev. Phytopathol. 26. 379-407.

YANG, C. H. \& CROWLeY, D. E., 2000. Rhizosphere microbial community structure in relation to root location and plant iron nutritional status. Appl. Env. Microbiol. 66. 345-351. 